\title{
Scenes Depicting Children in Service-work and Servitude Duties in Ancient Egypt
}

(A Comparative Study) ${ }^{1}$

\section{BY}

Mohamed Galal Abdulmoez, Prof. Sherief El Sabban and Dr. Engy El Kilany

Tourist Guidance Department, Faculty of Tourism and Hotels, Minia University

\section{Abstract}

Children of Middle and low classes participated in the work fields throughout the ancient Egyptian different kingdoms mainly for three reasons; to the Middle class "Sons, daughters and relatives of tomb owners", it was honorable representations intended to introduce them as own children in their service, while to the Low class "Laborers and foreigners", it was compulsory work especially to the foreigners who achieved servitude duties and risky tasks, but to the laborers it was a part of their life to support and assist their families funding. The aim of this study is to analyze the scenes describing children in the field work to specify their roles and classify their occupations, group and sex add to compare between these roles into different kingdoms considering the tasks committed to boys, girls or both gender of children.

Key words: Boy, girl, servant-boy, maid-girl, mourner-girl, children offering-bearer

\section{Introduction}


Depictions of children in service duties were common tasks in ancient Egypt and widely described on the tomb walls of three kingdoms where these duties of service and servitude were the easiest learning activities in comparative with other crafts activities which required talented, healthy and well trained children, but these criteria were skipped in the case of service-work this can be estimated from the status of servant boy with deformed back ${ }^{2}$ (tomb of Niankhkhnum, old kingdom PL.I), this explain the big number of children into this category. These service duties varied between funerary rites tasks, retinue's works and servitude's works in daily life scenes of nobles who got served by servant children in non agricultural, industrial or commercial situations.

The existence of children in the funerary rites and ritual scenes was essential in Old, Middle and New kingdoms, not only for the noble children of tomb owners or their relatives but for the children of laborer and servant classes who represented as individuals in the noble's entourage, however each class of them has specific duties to achieve; the noble children depicted as performers offering to the tomb owners like many scenes in all kingdoms, while the children of lower class depicted as workers doing their tasks and duties which committed to them as servants such as carrying sack of the deceased personal objects (tomb of Ni-maat-re ${ }^{3}$, Niankhkhnum ${ }^{4}$ and Hetep-HerAkhti $^{5}$ old-kingdom \& Amenemhat Tomb No.2 middle-kingdom ${ }^{6}$ \& tomb of Dhutmosi ${ }^{7}$, new-kingdom, Ex. PL.II), holding fan or sunshade upon nobles of tomb owners (in tomb of Meru ${ }^{8}$ old kingdom fig.4 \& tomb of Neferhotep ${ }^{9}$ fig. 8 , many Amarna tombs new kingdom).

This study follows a descriptive and annalistic methodology to achieve its aims and it intended the children of middle and low classes that were depicted achieving service-work only, the age which targeted in this paper is from childhood till puberty. Elite class of children "Royal" were not covered in this study.

\section{Recognizing the middle-class children}

There were many depictions for the children of tomb owners, their relatives and attendant children who distinguished from laborers 
children by the kind of task they achieved firstly and by posture and stature secondly or sometimes accompanied with a hieroglyphic text of their names, where about the main task of them was either offering presenters into the funerary ritual who offers presents to tomb owners - like in Old, Middle and New-kingdoms- or offer to the gods -Newkingdom only-, sometimes perform religious rituals (tomb of Senbi ${ }^{10}$ fig.5, Old-kingdom \& Nakhtamun ${ }^{11}$ PL.III, New-kingdom) or rarely assist in the burial furniture rites who carry and transport the objects of tomb owners that be buried into their tombs like; (tombs of Shpsi ${ }^{12}$ fig.3, Pepi ${ }^{\mathrm{c}}{ } \mathrm{Nkh}^{13}$ fig.6, Old-kingdom \& Pairi ${ }^{14}$ noble boy with stool upon head New-kingdom Wilkinson, 1979, fig.35.101.3) as apart of entourage works, but never depicted holding sunshade to tomb owners, carrying sack of the deceased personal objects in palanquin, or doing duties of servitude which committed to servants of lower class only. Secondly the posture and stature of noble children in Oldkingdom either represented with hair-style (tombs of Shpsi Junker, 1943, Abb.62 \& Mereruka Wilson, 1938, pl.82) or associated with individuals of tomb owner's families, sons, daughters and noble officials (tombs of Senedjemib-mehi fig.1, Iteti, Pepi ${ }^{\mathrm{c}}$ onkh, Nebet), then in Middle-kingdom there is only one scene which combined between hair-style and association with nobles (tomb of Chnemhotep Tomb No.3 Newberry, 1893, pl. XXXV), while in New-kingdom the situation is completely different where the majority depictions of children into funerary ritual and rites were seized by noble children as offering presenters marked with varied signs of hair-styles, wigs, accessories, association with tomb owners regularly, and mostly well dressed similar to them.

\section{Service roles of middle-class children}

Roles of middle-class children including the noble children of tomb owners or their attendants were varied in ancient Egypt and they had described as performers into the tomb owner's retinue achieves their roles into the funeral and cult rituals as next:

\section{Offering presenters}


- Child who depicted holds staff in hands or carries objects -rarely upon head or shoulder- to be presented personally to the tomb's owner El-Sharnouby, 2009, fig.11 or to deities during various occasions and ceremonies El-Sharnouby, 2009, fig.28.

- These staffs and objects are numerous, but the common and ordinary presents included birds and stem of plants in hands.

- Majority children who performed this role were the tomb owner's sons and daughters and often intended to be introduced by the tomb owners as their own children are in their service Ex. fig.9.

\section{Performer-child of religious rituals and funerary rites}

- Child who represented acting an extraordinary role related to funerary and religious reasons or who imitating religious-men into funeral processions PL.III.

- Such as boy assist in burning incenses to tomb owner (Senedjemib-mehi, Old-kingdom fig.1), boy carry an axe participating three soldiers to perform dance of war to deceased in funeral (Senbi, Old-kingdom Blackman, 1914, pl. III), noble boy with wooden box of incenses for performing the sacrifice rites (UserHat, new kingdom El-Sharnouby, 2009, fig.15), boy imitating the priests who perform the ceremonies of transporting the coffin to its tomb wearing a white ribbon of mourning fastened around their shaven skull (Nakhtamun Wilkinson, 1979, fig. 33.8.20, and two boys similar in Simut "Kyky" and Raames, Newkingdom), and child who perform prayers towards whether; deceased's anthropoid coffins or ancient Egyptian gods (Peshedu, Imn-nxt, Raames New-kingdom).

- Performer child of funerary rites was dedicated to boys in Old and New-kingdoms while religious rituals performed by both gender but in New-kingdom only.

\section{Mourner girls}


- Child who cry to express a highly state of grief for tomb owner's death throughout the funeral processions, raising hands on face approach to head in lamentation attitude and sometimes waving arms and through dust upon head acting the same behaviors that rest women' flock of tomb owner's family do ${ }^{15}$.

- Often mourner children were girl's role that accompanied with group of mourner women who took an obvious place into funeral, without specific dress, and in rarity depictions with head's bandeaux.

- The rare male children who depicted in mourning scenes associated with mourner women were dragged either; in young age of infancy and their act was reflection to their mother's attitude, or suckling age infants lapped into their mother's slings.

- The mourner child is unique and pure service role of new-kingdom only which never found neither old nor middle-kingdoms fig. 13.

- In few cases the features of mourning -raising hands on face approach to head and head's bandeaux- appeared on boys and girls who their role was Performer-child of religious rituals and funerary rites but the decisive criteria were association into crowd of mourner women and the specific position throughout funerary processions.

\section{Performer-child of burial furniture procession}

- The child who assist carrying and transporting object related to furniture materials that would be buried with tomb owner.

- This role worked out in old and new kingdoms (tombs of Shpsi, Pepi ${ }^{\mathrm{c} o n k h}$, old-kingdom \& Pairi, new-kingdom) Junker, 1943, Abb.62 \& Harpur, 2015, pl.241 \& Wilkinson, 1979, fig.35.101.3.

\section{Celebratory child}

- Child who is situated among sprightly crowd of attendants and followers in festive environments or expressing about their 
happiness and obeisance towards tomb owners or deities waving their hands Ex. Fig.12.

- This role held during new kingdom specifically at El-Amarna period where it was common role executed by boys and girls then reduced later (Neferhotep at Thebes, many celebratory children) Davies, 1903, pl. XIII, Davies, 1905, pl. XXXVI.

- Celebratory children might hold tree's branches in their hands or danced but in individual random celebrations and not in arranged acrobatics like professional dancers of new and old kingdoms.

\section{Service duties of low-class children}

The low-class children consists of the laborer's children who their parents work inside the palaces of nobles or who sent by their families to work into the noble's entourage in order to help them funding, this can be concluded from the kitchen dialogue between cooker and servant boy describing boy's activities as job and says "Back to work, you may summon the lads to eat bread ${ }^{16 "}$ (Pepic ${ }^{\mathrm{c}} \mathrm{onkh}$, old kingdom fig.4), on the other side some children who gone captives during wars and military expeditions or collecting of tributes from foreigner nations ${ }^{17}$, this class of children used by the nobles as servants to execute service works and duties for nobles, officials, followers and their families either by servitude methods or hiring them. Recognizing the low-class children on the private tomb's wall depended on the repeatedly features that used by the sculptors to differentiate them from the noble class children such as;

Firstly by exhausted stature, servility posture and trudged status see attitudes of next servant children in (tombs of Ukh-hotep fig.3, Niankhkhnum old kingdom \& Amenemhat Tomb No.2, Antefoker fig.5 middle kingdom \& Dhutmosi, Nebamun, Pairi new kingdom) Ex. PLs.I, II, IV. Secondly there was another way to figure out the low-class children by the nature of works that they depicted achieving which are connecting to slavery and servitude occupations like; carrying sandals, lean-sticks and other personal staffs, serve preparing food and beverage in kitchen, assisting nobles to have it or to feed them directly (kitchen works in Hetep-Her-Akhti ${ }^{18}$, Pepic ${ }^{c}$ onkh ${ }^{19}$ tombs 
of old kingdom \& prepare banquets and assist nobles to have it in Kahay $^{20}$, Teta-ankh "Imhetep" ${ }^{12}$ old kingdom,( Tetiky ${ }^{22}$, Rekhmeraa ${ }^{23}$, Amenmhet, Ipuky, Wah, Djeserkaracsonb ${ }^{24}$, Amenhotp-Si-se, Ptahemhet, Neferronpet, Nakht, Nebseny tombs of new kingdom) Ex. fig. 2 \& feed persons directly in Hetep-Her-Akhti, Petah-hotep old kingdom tombs) also works like storing provisions or transport tributes (Huya Davies, 1905, pl. XV, Mahu Davies, 1906, pl. XXIV at Amarna, Nebamun Söderbergh, 1957, Pl. XXII at Thebes, new kingdom Ex. fig.7). Mentioned previous examples may accept possibility of servitude or children hiring, but the next examples accept only slavery methods like; servant children execute varied duties in military camp regardless war risks (tomb of Horemheb at Memphis fig.11) and captive servant girls from harem participate in the palace activities (tomb of Tutu Davies, 1908, pl. XVII \& Ay Davies, 1908, pl. XXVIII at El-Amarna), therefore these duties of low-class children may classify as:

a) Duties accept possibility of hiring children or servitude methods as next:

\section{Offering bearers}

- Child who carry and transport offerings -often upon head or shoulder- during funerary rites and provision tasks in order to be stored in its destination and not intended to present it personally Ex. fig.5.

- Common duty throughout ancient Egyptian kingdoms included boys and girls (Davies, 1905, pl. XV \& Davies, 1906, pl. XXIV \& Söderbergh, 1957, Pl. XXII).

\section{Sunshade or fan bearers}

- The child who use primitive manmade tools for fanning or shading a nobleman to decrease fallen heat upon him with gesture to noble's majesty and slivery of child. 
- This duty was popular in El-Amarna period exactly associated with the royal family' servants to protect young princesses ( $E x$. Davies, 1903, pl. XXII \& Davies, 1903, pl. XXVI), but hardly found in old kingdom to serve tomb's owner (Lloyd, 1990, pl.7), while non in middle kingdom.

\section{Funerary servants of retinue}

- The child who ordered to do one or more unusual service-duties during funeral processions and these tasks related to burial furniture processes.

- Such as maid girl who carry on her head a tray upon which is a vase for ablution purposes (tomb of Ukh-hotep, old kingdom fig.3), and maid girl carries a basin with probably its ewer placed in right arm and holds cloths in left hand (tomb of Remni, old kingdom Kanawati, 2009, pl.46), trudged servant boys carrying and transport funerary box, two rods and a head-rest (the tomb of Nebamun, new kingdom Davies, 1925, pl. XXIV).

\section{Follower of craftsmen}

- The child who achieves service duties to craftsmen or officials maybe in off work time and place or during their work situations but in conditions; do not execute the same tasks of craftsmen around, do not involved in any processes of the handicraft itself, and to be the activities he do are under criteria and properties of service-work.

- Such as follower boy who serves the overseer -in off work time and place - to have his drink from a jar where he guides its mouth to overseer's lips and tips the vessel gently upwards ${ }^{25}$ (tombs of Hetep-Her-Akhti Mohr, 1943, fig.18 \& Petah-hotep Harpur, 2008, pl.209 old kingdom). The next cases are during craftsmen's work situations but under previous mentioned conditions (tomb of Niankhkhnum Harpur, 2010, detail.71 \& Pepiconkh fig.4 old kingdom \& Tutu Amarna Davies, 1908, pl. XX \& Nefer-Hotep I Thebes fig.6, new kingdom). 
- This duty dedicated to boys only, depicted in varied daily life scenes, and possible so far that it was common task throughout all kingdoms.

\section{Indoor maid girl and servant boy}

- The child who achieves home service duties related to cleanness, preparing food and serve at meals, banquets, offering tables and furniture arrangement.

- Such as servant boy stoops beneath the stool of his master (Tetaankh, old kingdom), maid girl wash her hands before serving the noble lady to have some fruits (Kahay, old kingdom fig.2). In new kingdom; servant girl smoothing down the white linen upon a fine bedstead and another stoops maid girl smoothing out the cushion of their lady's chair (User fig.10), servant boy arranging the bed of a lady and putting the headrest (Neferronpet Baud, M. 1935, pl. $X X V$ ), maid girl holds mirror and pot (tomb of May Söderbergh, 1957, pl. XXI(C) \& Nebamun Baud, M. 1935, fig.71), the servant boy and maid girl who serves the nobles to have their meal in varied banquet tomb's scene of (Tetiky, Rekhmeraa, Amenmhet, Ipuky, Wah, Djeserkaracsonb, Amenhotp-Si-se, Ptahemhet, Neferronpet, Nakht, Nebseny).

b) Duties with single possibility of slavery methods as next:

\section{Servant boy in military places}

- The child who achieves service-works in camps, wars and military places as slave and maybe was captured in battles, taken as a foreign tribute or the children of captured foreigners.

- Such as slave male children inside military camp behave as next; boy runs to fill up water jars, other boy throws down water to settle the dust, then child was riding on the mare, and one more boy carrying a basket with provisions (Horemheb, Memphis, new kingdom fig.11). 
- Although the scene of children in military places belongs to new kingdom and it has not equivalent in the other kingdoms, but big number of obvious children involved in many activities into one scene may assume that it was common in ancient Egypt or at least during new kingdom era.

\section{Servant girl into palace's Harem}

- The girl who adjoined to Harem section into palaces of nobles to be used as slave girl and maybe also captured in wars, taken as a foreign tribute or belongs to the offspring of captured foreigners.

- Like female servants and slaves involved in many activities at ElAmarna (tomb of Tutu Davies, 1908, pl. XVII \& Ay Davies, 1908, pl. XXVIII at El-Amarna), negro or Nubian maid girl with two tufts of hair nursing a noble kid into sling during funerary (tomb of Qen), one more negro servant girl washing the foot of her prosperous lady who is shown suckling her child and putting her leg upon a jar (Ostraca, Deir el-Medina fig.14).

\section{Personal servant}

- The child who follows his master carrying his personal objects (sacks, sandals, clothes and leaning sticks) either in palanquins or different life activities.

- This task was common through out all kingdoms and practiced by boys only to serve the noblemen.

- Examples for this task are various as next; in old kingdom, boy carrying sack of personal objects and trudge in palanquin processions (Ni-maat-re PL.II, Niankhkhnum, Hetep-Her-Akhti Mohr, 1943, fig.44), in middle kingdom, boy carrying personal staff (Amenemhat "Tomb No.2" Newberry, 1893, pl. XIII), in new kingdom, small boy carries a pair of sandals strapped to his left wrist and a white cloth-bag in his right hand (Dhutmosi Hegazy, 1983, pl.7).

\section{Concluding Remarks:}




\section{A- Properties of service-work}

Properties of service-work in ancient Egypt were comparative according to the classes of children and the specific activities of each class as next;

The middle-class children their roles were limited and simple where the majority of these roles did not require hard physical efforts and distinguished by the honorable representations more than it being a work although they represented lusty in all cases, moreover the appearance motive was either introducing them showing their relationship to tomb owners or teaching them the activities of nobles.

The low-class children their duties and tasks were varied and has different properties mixed between; simplicity as the common property of almost tasks, difficulty in few works which required physical efforts to carry and transport staffs, and risky in rare works which executed into military places, while the motive of work was benefits and support family to children of laborers or forced work to children of slaves.

Finally the principle of punishment if the child mistake or shorten in his work is also documented in the service-work category where child bastinadoed because he/she not delivered full quota of provisions ${ }^{26}$ (tomb of Nebamun, new kingdom Söderbergh, 1957, Pl. XXII).

\section{B- Signs of children in service-work category}

In old kingdom the traditional signs of low-class children in both gender were; shaven headed, slim body, thin limbs, small figure size, nudity, semi-nakedness, uncircumcised penis for boys, slightly outward side-breast carving for girls, and without accessories (except Niankhkhnum's servant girl with a fake pendant), while the middleclass children marked by hairstyle (tombs of Shpsi and Mereruka) and accessories (tomb of Snb, boy with collar and bracelet ${ }^{27}$ ).

In middle kingdom the children' signs of both classes followed the old kingdom except in nudity features which was denied at all. 
In new kingdom the differences were in three aspects; the first is using side-lock of youth to low-class children but only in El-Amarna art to children fan bearers possible to identify them as distinguished servants of royal family, the second is ornamenting the indoor maid girls with hairstyles and accessories "wigs, bracelets and girdles" probably for reasons related to beauty, hygiene and standard look of special girls deal directly with nobles in banquets (Ex. Davies, 1944, pl. LXIV \& Davies, 1925, pl. VII \& Söderbergh, 1957, pl. XXI(C) \& Baud, 1935, fig.71), the third is depicting girls with pubic hair as unique sign for girls at this era (Ex. Andre, 1954, fig.39 \& Davies, 1925, pl. VII \& Davies, 1941, pl. XXV).

\section{C- Chart shows the classification of service-work:}




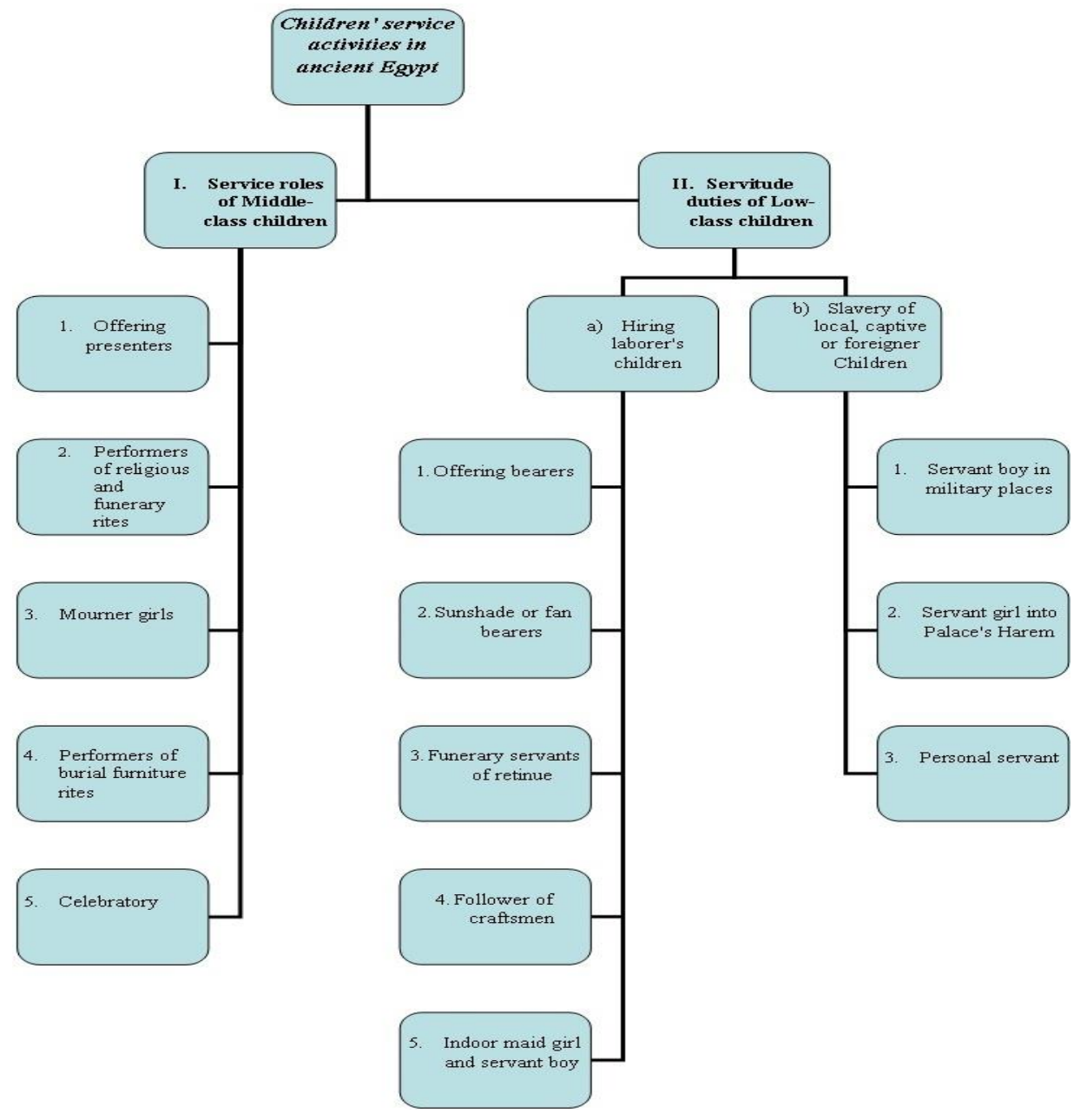

\section{References:}


- Abdul-Qader, M. (1966), The Development of the funerary believes and practices displayed in the private tombs of the new kingdom at Thebes, Cairo

- Andre L. (1954), Les chefs-d'ouvre de la peinture égyptienne, Paris.

- Badawy A. (1976), The tombs of Iteti, Seshm Cankh-Ptah and Kaemnofrt, Los Angeles.

- Baud M, (1935), Les Dessins Ébauchés de la Nécropole Thébaine (au Temps du Nouvel Empire), Le Caire

- Blackman, A.M. (1915-1953), The Rock Tombes of Meir I, II, $\mathrm{V}$, London

- Brovarski E. (2001), The Senedjemib Complex. Part 1. The Mastabas of Senedjemib Inti (G 2370), Khnumenti (G 2374), and Senedjemib Mehi (G 2378), Boston.

- Bruyère, (1959), La Tombe No. 1 de Sen-Nedjem à Deir ElMedineh, MIFAO 88, Le Caire.

- Budge, Wallis (1914), Wall decorations of Egyptian tombs : illustrated from examples in the British museum, London.

- Davies, N.G (1901), The rock cut tombs of Shaikh Said. London.

- Davies, N.G (1903-8), The Rock tombs of El-Amarna I, II, III, $I V, V, V I$, London.

- Davies, N.G (1917) The Tomb of Nacht at Thebes, New York.

- Davies, N.G (1925), "The Tomb of Tetaky at Thebes (No. 15)", JEA XI.

- Davies, N.G (1925), The Tomb of Two Sculptors at Thebes, New York

- Davies, N.G (1927), Two Ramesside Tombs at Thebes, New York.

- Davies, N.G (1933), The Tomb of Nefer-Hotep at Thebes I, II, New York

- Davies, N.G (1941), The Tomb of the Vizier Ramose, London

- Davies, N.G (1963), The Tomb of Rekh-Mi-Rê at Thebes, New York. 
- Davies N.G and Gardiner A.H (1915), The Tomb of Amenemhet (No. 82), London.

- Davies, N.G and Gardiner, A.H. (1920), THE Tomb of Antefoker, vizier of Sesostris and his wife Senet, London.

- Davies N.G and Gardiner A.H. (1936), Ancient Egyptian Paintings I, II, Chicago

- Davies N.G and Gardiner A.H. (1948), Seven Private Tombs at Kurnah, London.

- Duell, Prentice (1938), The Mastaba of Mereruka I, II, Chicago.

- El-Kilany, E. (2007), Scenes depicting female occupations in ancient Egypt at the private tombs from the old kingdom to the end of the new kingdom, unpublished $\mathrm{PhD}$, Minia University.

- El-Sharnouby, R. (2009), The Children Scenes in the Individual Tombs of Thebes in The New Kingdom, unpublished $\mathrm{PhD}$, Alexandria University.

- Greenlees T.H (1923), “An Unusual Tomb Scene from Dirâa Abu 'L-Naga', JEA IX

- http://www.osirisnet.net/tombes/artisans/sennedjem1/e_senned jem1_02.htm

- Harpur, Y. and Scremin, P. (1987), Decoration in Egyptian tombs of the Old-Kingdom, London; New York.

- Harpur, Y. and Scremin, P. (2008), The chapel of PtahHotep, OEE, Oxford.

- Harpur, Y. and Scremin, P. (2010), The Chapel of Niankhkhnum and Khnumhotep, OEE. Oxford.

- Harpur, Y. and Scremin, P. (2015), The chapel of Nefer \& Kahay, OEE, Oxford.

- Hassan, S. (1936), Excavations at Giza II, Cairo.

- Hassan, S. (1975), The Mastaba of Neb-Kaw-Her, Cairo.

- Hegazy and Tosi (1983), A Theban Private tomb Tomb no. 295, Mainz am Rhein.

- Johnson, W. Raymond (1997), The Hidden Tombs of Memphis: New Discoveries from the Time of Tutankhamun and Ramesses the Great, Chicago.

- Junker, H. (1934), Giza,VI, DAWW, Wien. 
- Kanawati (1988), The Rock Tombs of El-Hawawish : The Cemetery of Akhmim. Vol. VIII, Sydney.

- Kanawati (2009), The Teti cemetery at Saqqara. Volume 9. The Tomb of Remni, Oxford.

- Kanawati (2014), The Cemetery of Meir. Volume II. The tomb of Pepyankh the Black, Oxford.

- Lashien (2013), The Chapel of Kahai and his family, Oxford

- Lloyd, B. (1990), Saqqara Tombs. II. The mastabas of Meru, Semdenti, Khui and others, London.

- Manniche, L. (1988), The Wall Decoration of Three Theban Tombs (TT 77, 175 and 249), Copenhagen.

- Megan C. O'Neill (2015), The Decorative Program of the Eighteenth-Dynasty Tomb of Pairy (TT 139), Thesis, Georgia State University

- Mohr, H. (1943), The mastaba of Hetep-her-akhti, Leiden.

- Newberry, P. (1893) Beni Hassan I, II, London.

- Söderbergh, T.S (1957), Four Eighteenth Dynasty Tombs (Private Tombs at Thebes), I, Oxford.

- Wilkinson, J. (1878), The Manners and Customs of the Ancient Egyptians. A new edition revised and corrected by Samuel Birch. Vol. II, London.

- Wilkinson, K. (1983), Egyptian Wall Paintings: The Metropolitan Museum of Art's Collection of Facsimiles, New York.

\section{List of plates:}

PL.I Servant boy with a badly deformed back, the chapel of Niankhkhnum \& Khnumhotep, after Harpur, 2010, pl.150

PL.II Young servant-boy from entourage carrying a bag for clothes, a basin and other objects, after Hassan, 1930, fig 240

PL.III Boy imitating the priests who perform the ceremonies of transporting the coffin to its tomb wearing a white ribbon of mourning fastened around their shaven skull, after K. Wilkinson, 1979, fig. 33.8.20 
PL.IV Trudged, nude and shaven-headed boy carrying a funerary box, two rods and a head-rest, after Davies, 1925, pl. XXIV

\section{$\underline{\text { List of figures: }}$}

Fig.1 Boy assists in burning incenses following the incense-burner priest, after Brovarski, 2001, fig. 113

Fig.2 Nude shaven headed maidservant girl cleansing her hands before serving the noble lady, after Harpur, 2015, pl.241

Fig.3 Young maid-girl carrying on her head a tray upon which is a vase, after Blackman, 1915, pl. III

Fig.4 Servant boy at kitchen carry tray of food staffs and turns his head backwards replying the craftsman, after Blackman, 1953, pl. XXX

Fig.5 Maid girl represented shaven headed and carrying a basin on her head, after Davies, 1920, pl. XXVI

Fig.6 Boy carrying personal staff of the overseer in carpentry scene, after Davies, 1933, pl. XLVII

Fig.7 Little boy and a probably girl carrying filled sack and big fish on their shoulders to transport provisions, after Davies, 1906, pl. XXIV

Fig.8 Fan bearer-child represented nude with short hair and fan in hand, after Davies, 1933, pl. LII

Fig.9 Nude little boy and three naked girls offering presents to their parents, after Andre, 1954, fig.39

Fig.10 Two small indoor servant girls are smoothing down the white linen upon a fine bedstead and smoothing out the cushion of seat, after E. El-Kilany, 2007, fig. 3-44

Fig.11 Four male children inside military camp are involved into servitude duties, after Martin, 1991, fig. 22

Fig.12 Small girl celebrating holding stem of flower in obeisance rites scene, after Davies, 1903, pl. XIII

Fig.13 So small nude girl with partial shaven head pouring dust on her head as crowd of young girls and mourner women do, after Davies, 1941, pl. XXV

Fig.14 Negro servant girl washing the legs of her mistress, after شكل 1966, 4 ,عبدالعزيز صالح 


\section{Plates}
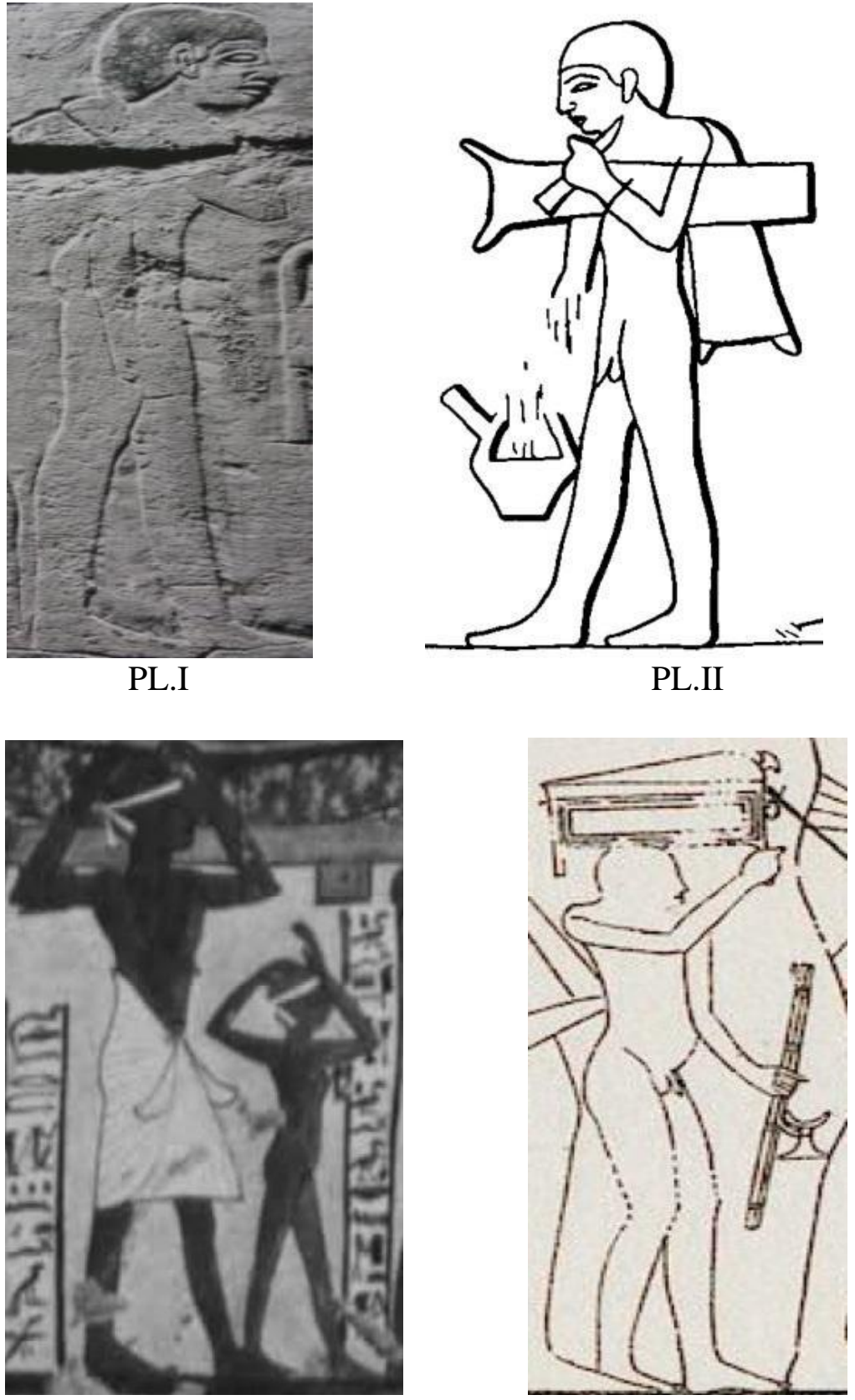

858 
PL.III

Old kingdom:

\section{Figures}

\section{PL.IV}

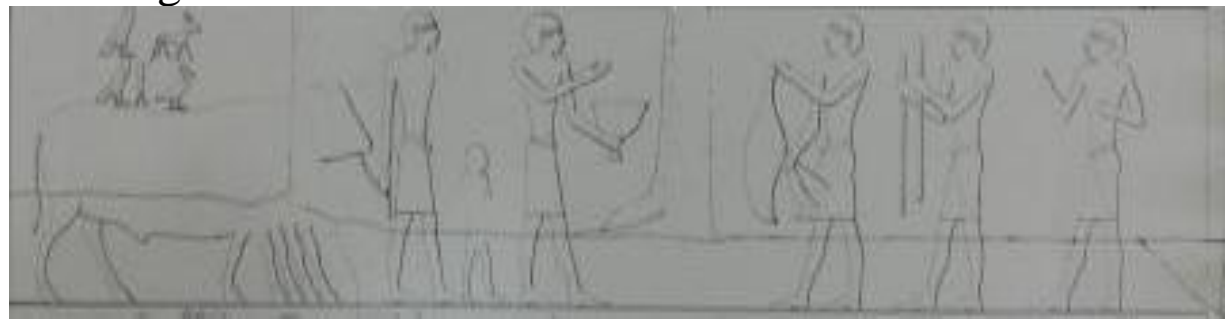

Fig.1

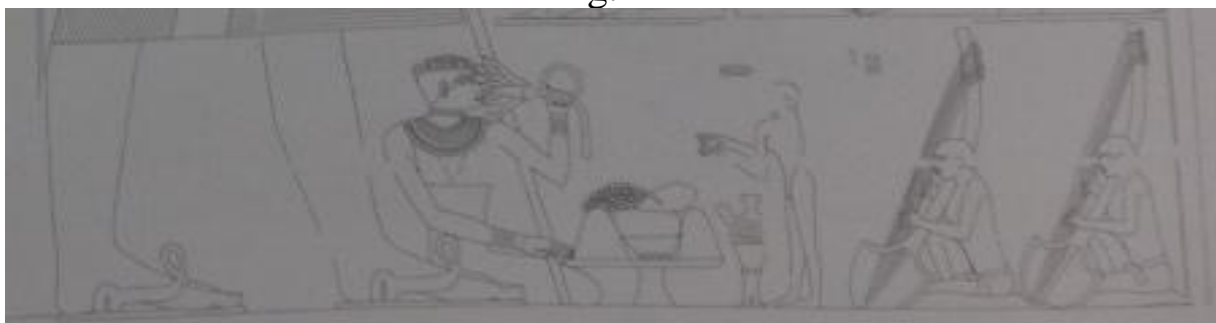

Fig.2

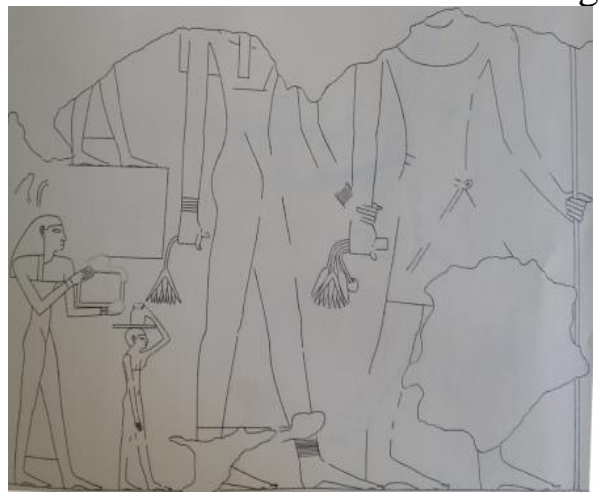

Fig. 3

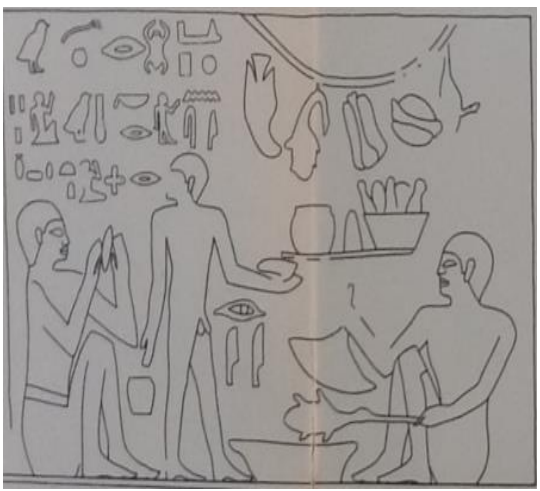

Fig.4

Middle kingdom: 


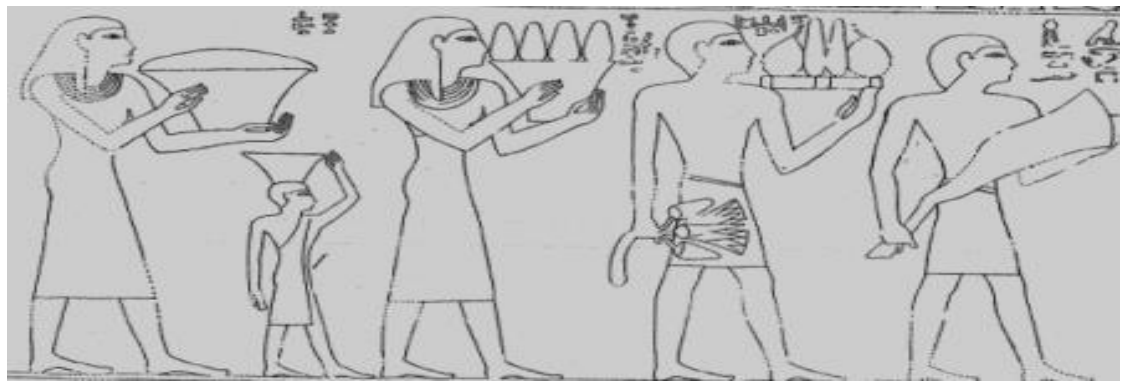

Fig.5 
New kingdom:

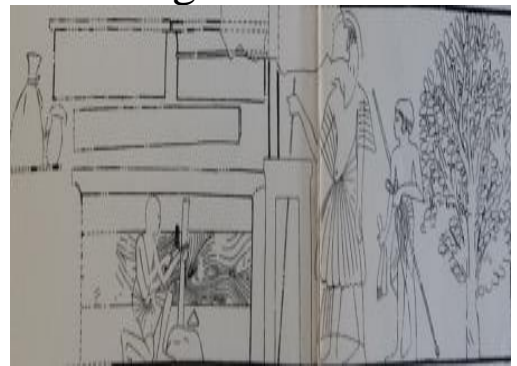

Fig.6

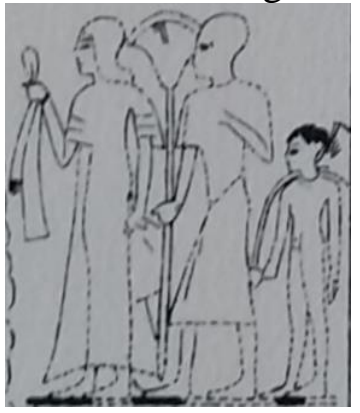

Fig. 8

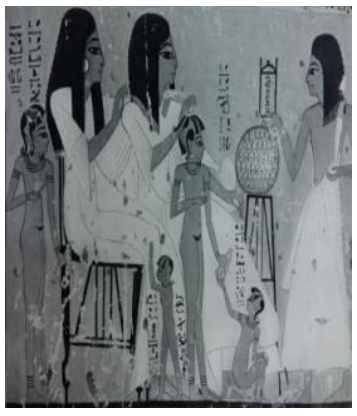

Fig.9

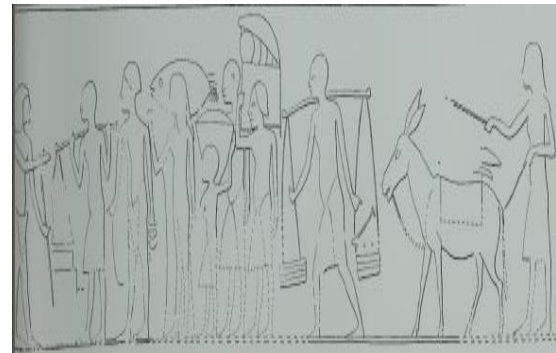

Fig. 7

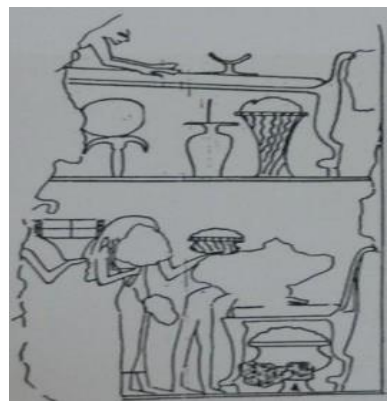

Fig.10

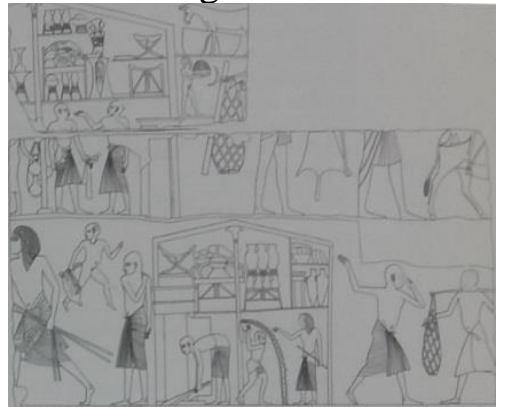

Fig.11

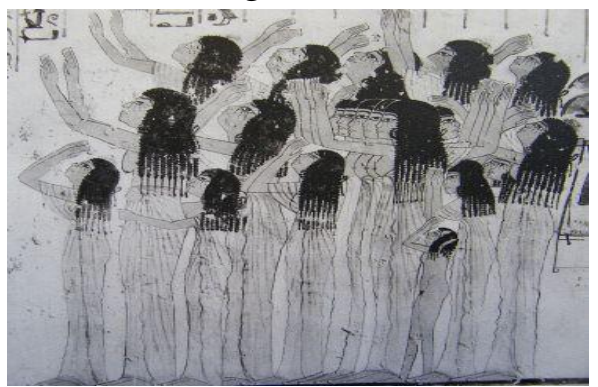

Fig.13

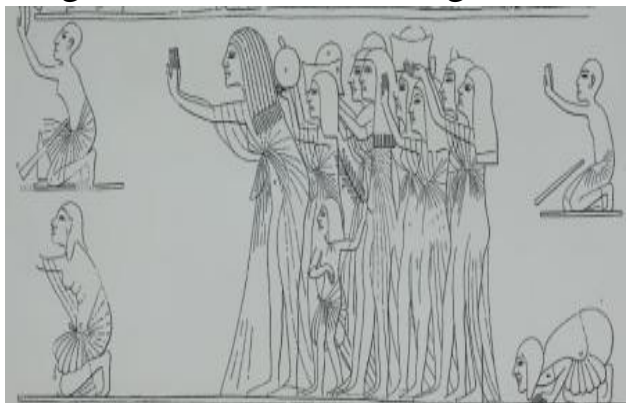

Fig. 12

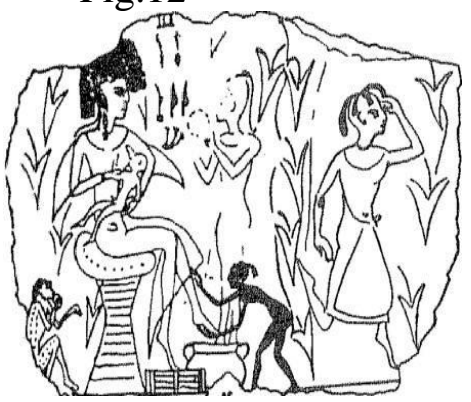

Fig. 14 
${ }^{1}$ This study is a part from a dissertation submitted in accordance with the requirements of Minia University for the Master Degree under the title of "Scenes depicting childhood at private tombs of ancient Egypt from the beginning of the Old-kingdom till the end of the New-kingdom ". It is under the supervision of: 1- Prof. Dr: Sherief El Sabban (Prof. of Egyptology and Archaeology-University of Minia). 2- Dr. Engy El Kilany (Assis. Prof. of Egyptology University of Minia).

${ }^{2}$ A body care portrait for barbers and manicurists included a follower of manicurist described as servant boy with a badly deformed back, near to the manicurist's equipment as gesture for serving him in carrying staffs. Harpur (2010), The chapel of Niankhkhnum \& Khnumhotep, Oxford, p.144

${ }^{3}$ Hassan (1936), Excavations at Giza II, Cairo, p. 221. Hassan identified the figure either young boy or dwarf, but his features of uncircumcised, slim and tall body declares that he is a boy added to repeatedly scenes of servant boy with a sack in palanquin confirms that this identification is boy similar to those of Niankhkhnum and Hetep-her- akhti.

${ }^{4}$ Thin naked servant-boy from retinue is carrying a walking stick and a filled sack. Harpur (2010), The chapel of Niankhkhnum \& Khnumhotep, p.398-9

${ }^{5}$ Personal staff boy-bearer is carrying a sack of cloths and a pair of sandals. Mohr (1943), The Mastaba of Hetep-Her-Akhti, Leiden, p.79

${ }^{6}$ Newberry (1893), Beni Hassan I: Tomb No.2, The tomb of Amenemhat, London, Pl. XIII. Newberry didn't give much details about identification of that attendant therefore the researcher concluded the identification as boy from overstatement of his tiny figure in comparison with the other attendant arround.

7 The smaller male figure at rear that carries a pair of sandals strapped to his left wrist and a white cloth-bag in his right hand. Hegazy (1983), A Theban Private tomb (tomb no.295), Mainz am Rhein, p.13

${ }^{8}$ Lloyd (1990), Saqqara tombs II, The Mastabas of Meru, Semdenti, Khui, and others, London, p.9. Lloyd abbreviated the details about the sun-shade bearer while the researcher abut on his features of shaven headed, tiny figure, thin and slim body, add to his unique spot (frontally and up high level closer to fan-bearer girl of Neferhotep in new kingdom) to support the sun-shade upon the noble in contrary of other bearers in many scenes who support it from the back with low ground level.

9 At the end of the topmost subregister depiction for fan bearer-child represented nude with short hair and fan in hand. Davies (1933), The Tomb of Neferhotep at Thebes II, New York, P.63

${ }^{10}$ Three soldiers performing the dance of war followed by a boy carries a battle-axe upon his right shoulder. Blackman (1953), The Rock tombs of Meir V, London, p.39 \& Kanawati (2014), The cemetery of Meir II, The tomb of Pepyankh the Black, Oxford, p.51-2 
${ }^{11}$ Boy imitating the priests who perform the ceremonies of transporting the coffin to its tomb. Davies and Gardiner (1948), Seven private tombs at Kurnah, London, p.36

12 Two naked children; boy first presented with the left hand on a goose neck and holds in the right-hand a jug with cord, the girl last figure with pigtail holding a sack in right hand and washer-cloth in left hand. Junker (1934), Giza VI, Die Mastabas des Nefer, Kedfi, und Kahief, DAWW, Wien, p.178

${ }^{13}$ Boy carries a vase on his left shoulder. Blackman (1953), The Rock tombs of Meir $V$, p.34

${ }^{14}$ Small boy is carrying an elegant black chair over his head. Megan C. O'Neill (2015), The Decorative Program of the Eighteenth-Dynasty Tomb of Pairy (TT 139), Thesis, Georgia State University, p.45

${ }^{15}$ Davies (1941), The Tomb of the Vizier Ramose, London, pp. 25-26 \& pl. XXV

${ }^{16}$ Blackman (1953), Meir V, p.34

17 Johnson (1997), The Hidden Tombs of Memphis: New Discoveries from the Time of Tutankhamun and Ramesses the Great, Chicago, pp.57-58

${ }^{18}$ Mohr (1943), The Mastaba of Hetep-Her-Akhti, pp.49, 60 \& figs. 18, 30

${ }^{19}$ Blackman (1953), op. cit., p.34

${ }^{20}$ Lashien (2013), The Chapel of Kahai and his family, Oxford, p.41 \& Harpur (2015), The chapel of Nefer \& Kahay, Oxford, p.399

${ }^{21}$ Naked servant boy stoops beneath the stool. Davies (1901), The rock tomb of Sheikh Said, London, p.33 \& pl. XXIX

${ }^{22}$ Davies (1925), JEA XI : The Tomb of Tetaky at Thebes (No. 15), pp.15-16 \& pl. IV

${ }^{23}$ Davies (1963), The Tomb of Rekh-Mi-Rê at Thebes, Vol. II, New York, PL. LXIV

${ }^{24}$ Both girls must be quite young, since they would hardly otherwise have been represented without clothes" Davies stated. See Davies and Gardiner (1936) Ancient Egyptian paintings III, Chicago, P.75

${ }^{25}$ Harpur (2008), The chapel of Petah-hotep, Oxford, p.314

${ }^{26}$ Söderbergh (1957), Four Eighteenth Dynasty Tombs, (Private Tombs at Thebes), I, Oxford, pp. 24-25

${ }^{27}$ Harpur (1987), The Decoration in Egyptian tombs of the Old-Kingdom, fig.67 